\title{
Effect of Chlorination on Microbiological Quality of Effluent of a Full-Scale Wastewater Treatment Plant
}

\author{
Ioanna Zerva ${ }^{1,2}$, Nikolaos Remmas ${ }^{1}$, Ifigeneia Kagalou ${ }^{2} \mathbb{D}$, Paraschos Melidis ${ }^{1}$, Marina Ariantsi ${ }^{1}$, \\ Georgios Sylaios ${ }^{3}$ id and Spyridon Ntougias ${ }^{1, *(D)}$
}

1 Department of Environmental Engineering, Laboratory of Wastewater Management and Treatment Technologies, Democritus University of Thrace, Vas. Sofias 12, 67132 Xanthi, Greece; izerva@env.duth.gr (I.Z.); nremmas@env.duth.gr (N.R.); pmelidis@env.duth.gr (P.M.); mariaria@env.duth.gr (M.A.)

2 Department of Civil Engineering, Democritus University of Thrace, Vas. Sofias 12, 67132 Xanthi, Greece; ikagkalo@civil.duth.gr

3 Department of Environmental Engineering, Laboratory of Ecological Engineering and Technology, Democritus University of Thrace, Vas. Sofias 12, 67132 Xanthi, Greece; gsylaios@env.duth.gr

* Correspondence: sntougia@env.duth.gr; Tel.: +30-25410-79313

Citation: Zerva, I.; Remmas, N.; Kagalou, I.; Melidis, P.; Ariantsi, M. Sylaios, G.; Ntougias, S. Effect of Chlorination on Microbiological Quality of Effluent of a Full-Scale Wastewater Treatment Plant. Life 2021, 11, 68. https://doi.org/ 10.3390/life11010068

Received: 7 December 2020

Accepted: 14 January 2021

Published: 19 January 2021

Publisher's Note: MDPI stays neutra with regard to jurisdictional claims in published maps and institutional affiliations.

Copyright: (C) 2021 by the authors Licensee MDPI, Basel, Switzerland. This article is an open access article distributed under the terms and conditions of the Creative Commons Attribution (CC BY) license (https:// creativecommons.org/licenses/by/ $4.0 /)$

\begin{abstract}
The evaluation of effluent wastewater quality mainly relies on the assessment of conventional bacterial indicators, such as fecal coliforms and enterococci; however, little is known about opportunistic pathogens, which can resist chlorination and may be transmitted in aquatic environments. In contrast to conventional microbiological methods, high-throughput molecular techniques can provide an accurate evaluation of effluent quality, although a limited number of studies have been performed in this direction. In this work, high-throughput amplicon sequencing was employed to assess the effectiveness of chlorination as a disinfection method for secondary effluents. Common inhabitants of the intestinal tract, such as Bacteroides, Arcobacter and Clostridium, and activated sludge denitrifiers capable of forming biofilms, such as Acidovorax, Pseudomonas and Thauera, were identified in the chlorinated effluent. Chloroflexi with dechlorination capability and the bacteria involved in enhanced biological phosphorus removal, i.e., Candidatus Accumulibacter and Candidatus Competibacter, were also found to resist chlorination. No detection of Escherichia indicates the lack of fecal coliform contamination. Mycobacterium spp. were absent in the chlorinated effluent, whereas toxin-producing cyanobacteria of the genera Anabaena and Microcystis were identified in low abundances. Chlorination significantly affected the filamentous bacteria Nocardioides and Gordonia, whereas Zoogloea proliferated in the disinfected effluent. Moreover, perchlorate/chlorate- and organochlorine-reducing bacteria resisted chlorination.
\end{abstract}

Keywords: waterborne pathogens; effluent quality; toxic cyanobacteria; chlorination; filamentous bacteria; microbial ecology of effluent

\section{Introduction}

Wastewater treatment plants (WWTPs) usually focus on the removal of nutrients and suspended solids in order to safely dispose of the effluent in a recipient aquifer. However, WWTPs could potentially constitute a source of the dispersal of microorganisms in the environment, as microbes are not completely removed during treatment [1,2]. Thus, the conventionally treated effluent may still include a pathogenic charge, such as bacteria and protozoa, including harmful cyanobacteria capable of producing toxins under certain conditions [2-4]. Moreover, chemical contaminants, such as pharmaceuticals and personal care products (PPCPs), are also released into the environment, along with the dispersal of antibiotic resistance genes, thus strengthening environmental concerns $[4,5]$. This is mainly due to the limited efficiency of the conventional treatment processes, a fact that can lead to increased human health risk associated with food web and water contamination [1,5-7]. As a consequence, the implementation of effective disinfection 
methods has become increasingly necessary in order to eliminate the potential microbial risk posed by the effluent discharge [6,8].

Several disinfection methods, such as chlorination [8,9], UV radiation [1,6,9,10], ozonation $[6,11]$, as well as peracetic acid $[12,13]$ and hydrogen peroxide addition $[10,14-16]$, have been employed to improve microbiological effluent quality. Each disinfection method relies on a specific inactivation mechanism, such as DNA damage, enzyme denaturation, and cell wall and membrane disruption [6]. For instance, sodium hypochlorite $(\mathrm{NaClO})$ exerts a strong oxidizing capacity, affecting cell membrane structure, protein functionality and DNA replication [17]. Moreover, advanced oxidation processes (AOPs), in which highly reactive hydroxyl radicals are produced by primary oxidants, such as ozone, hydrogen peroxide and oxygen in combination with UV or a catalyst, are suitable methods for the microbial inactivation of secondary treated wastewater [18].

Even though chlorination is a commonly applied disinfection method, its effect on the bacterial community's structure in the effluent deserves further evaluation [8]. The microbiological quality of the effluent nowadays relies on the assessment of certain microbial indicators, which include total and fecal coliforms and enterococci. At the same time, little is known about the fate of waterborne pathogens able to resist disinfection, being released in aquatic environments $[4,6,19]$. In addition, coliform indicators may be susceptible to conventional chemical disinfectants, and possibly do not reflect precisely the occurrence of pathogens $[19,20]$. Indeed, the application of culture-dependent approaches provides a coarse estimation of the microbial risk in the discharged effluent, a fact that leads to an increased uncertainty regarding the evaluation of its microbiological quality [19]. On the other hand, massive amounts of sequencing data are obtained by the application of high-throughput molecular techniques, providing an accurate mapping of microbial communities, thus allowing the more precise evaluation of the disinfection methods applied in wastewater treatment [21].

Despite the fact that the effectiveness of common disinfection methods has been examined in various research works using microbial indicators $[17,20,22,23]$, a few studies have been performed through the use of culture-independent techniques to access microbiological effluent quality $[3,24]$. The aim of the present study was to evaluate the effectiveness of chlorination as a disinfection method against bacterial pathogens and key physiological groups of bacteria detected in the effluent of a full-scale wastewater treatment plant. In order to achieve this goal, we investigated the bacterial communities in the effluent prior to and after chlorination using the high-throughput amplicon sequencing approach.

\section{Materials and Methods}

The effluent of a full-scale municipal wastewater treatment plant (Evros region, Thrace, Greece) consisting of a primary sedimentation tank, an aerobic tank and a secondary clarifier was analyzed to investigate the effect of chlorination on the microbiological quality of the effluent. The chlorination of the effluent in the wastewater treatment plant was performed by adding sodium hypochlorite to achieve a final residual chlorine concentration of $0.2 \mathrm{mg} / \mathrm{L}$ under a contact time of $30 \mathrm{~min}$. Three distinct sampling procedures were made in a period of one month in order to collect altogether three non-chlorinated and three chlorinated effluent samples. All samples were collected in sterile containers and transferred at $5{ }^{\circ} \mathrm{C}$ within an hour to the laboratory for the immediate processing of the physicochemical analyses and DNA extraction. Genomic DNA was stored at $-80^{\circ} \mathrm{C}$ for downstream analyses.

\subsection{Determination of Wastewater Physicochemical Characteristics}

To determine the physicochemical characteristics, samples were collected from the influent (raw wastewater) and the effluent (treated wastewater discharged after chlorination in the recipient) of a full-scale wastewater treatment plant. Biochemical oxygen demand $\left(\mathrm{BOD}_{5}\right)$, chemical oxygen demand (COD) and total suspended solids (TSS) were determined based on the protocols described in the standard methods for the examination of water 
and wastewater [25]. The cadmium reduction method was applied for the quantification of nitrate's reduction to nitrite, whereas nitrites were assessed colorimetrically at $453 \mathrm{~nm}$ through the addition of sulfanilamide/(1-naphthyl)ethylenediamine-dihydrochloride indicator [25].

\subsection{DNA Extraction, Illumina Sequencing, Diversity Indices Estimation and Statistical Analyses}

Prior to and after chlorination, genomic DNA was obtained after effluent filtration and DNA extraction from the filter retaining the microorganisms (pore size of $0.22 \mu \mathrm{m}$ ) through the use of Wizard ${ }^{\circledR}$ Genomic DNA Purification Kit (Promega, Madison, WI, USA), following the manufacturer's instructions.

PCR amplification of the V1-V3 region of the 16S rRNA gene was conducted using the bacterial universal primers 27F (5'-AGR GTT TGA TCM TGG CTC AG-3') and 519R (5'-GTN TTA CNG CGG CKG CTG-3') [26]. A thermo-cycle program consisting of $3 \mathrm{~min}$ DNA denaturation at $94{ }^{\circ} \mathrm{C}$, a pool of 30 cycles of $30 \mathrm{~s}$ DNA denaturation at $94{ }^{\circ} \mathrm{C}, 40 \mathrm{~s}$ primer hybridization at $53{ }^{\circ} \mathrm{C}$, and $1 \mathrm{~min}$ DNA extension at $72{ }^{\circ} \mathrm{C}$ followed by a $5 \mathrm{~min}$ termination step at $72{ }^{\circ} \mathrm{C}$, was carried out. The reaction mixture was prepared by using "Qiagen HotStarTaq Plus Master Mix Kit" (Qiagen, Valencia, CA, USA) and amplified products were purified via the use of Ampure XP beads (Pacific Biosciences, Menlo Park, CA, USA). Illumina sequencing reactions were conducted in a MiSeq apparatus at "Mr DNA". Sequencing data were deposited in the SRA database at NCBI under the BioProject ID PRJNA681028.

All amplicons obtained were subjected to demultiplexing and trimming, and N(s)containing sequences, or reads with inappropriate length size or low-quality, were discarded [27]. Assembled sequences were improved in quality and chimeras were excluded through the use of USEARCH v.11 [28]. The clustering of non-chimeric reads into operational taxonomic units (OTUs) (number of reads $\geq 2$ ) was conducted by using the -cluster_otus option. Genus-level taxonomic assignments were made using RDP (Ribosomal Database Project). The MicrobiomeAnalyst platform was employed to calculate the diversity indices of the microbial communities of wastewater prior to and after chlorination [29]. Chao1, Fisher, Shannon and Simpson indices were assessed to uncover alpha-diversity. In order to access beta-diversity, principal coordinates analysis (PCoA) was conducted in the MicrobiomeAnalyst platform by using the Bray-Curtis algorithm, followed by permutational multivariate analysis of variance (PERMANOVA).

Analysis of variance (ANOVA) was performed using PAST v.3.25 [30] to assess differences among the relative abundances of the identified bacterial taxa, either prior to (marked as lowercase letters) or after chlorination (marked as uppercase letters). Student's $t$-test was carried out to identify statistically significant differences for the calculated diversity indices prior to and after chlorination, at a probability p lower than $0.01\left(^{* *}\right)$ or $0.05\left(^{*}\right)$.

\section{Results}

The BOD and COD removal efficiencies in the full-scale wastewater treatment plant exceeded $89 \%$ (Table 1). Moreover, the TSS were highly decreased in the effluent, indicating biosolids removal of $93.8 \pm 0.2 \%$ (Table 1 ).

Table 1. Physicochemical characteristics of influent and effluent of the full-scale wastewater treatment plant (WWTP) (Mean \pm SE, $\mathrm{n}=3$ ).

\begin{tabular}{cccc}
\hline Parameter & Influent & Effluent & Removal (\%) \\
\hline $\mathrm{BOD}_{5}(\mathrm{mg} / \mathrm{L})$ & $363 \pm 5$ & $17.3 \pm 0.5$ & $95.2 \pm 0.1$ \\
$\mathrm{COD}(\mathrm{mg} / \mathrm{L})$ & $626 \pm 17$ & $67.1 \pm 2.4$ & $89.1 \pm 0.4$ \\
$\mathrm{TSS}(\mathrm{mg} / \mathrm{L})$ & $311 \pm 7$ & $18.9 \pm 0.7$ & $93.8 \pm 0.2$ \\
$\mathrm{NO}_{3}{ }^{-}-\mathrm{N}(\mathrm{mg} / \mathrm{L})$ & - & $9.4 \pm 0.5$ & - \\
\hline
\end{tabular}


After quality filtering, 522,025 sequencing reads (out of 766,896 in total) were analyzed. The clustering of non-chimeric reads into operational taxonomic units (OTUs) resulted in the identification of 560 and 467 OTUs prior to and after chlorination, respectively.

The major bacterial taxa found in the effluent prior to and after chlorination are shown in Figure 1. Minor taxa ( $<1 \%$ of the total reads) are listed in Supplementary Table S1. The genus Bacteroides was a predominant taxon in the effluent prior to chlorination with a relative abundance of $6.36 \pm 1.87 \%$ of the total reads, followed by members of the genera Flavobacterium (5.98 $\pm 0.99 \%)$, Clostridium ( $4.20 \pm 0.86 \%)$, Sphingobacterium $(3.61 \pm 0.31 \%)$, Candidatus Accumulibacter ( $3.31 \pm 0.29 \%)$ and Dechloromonas $(3.17 \pm 0.21 \%)$ (Figure 1$)$. After disinfection, Bacteroides remained the dominant taxon, indicating the resistance of this genus to chlorination (Figure 1). In addition, Arcobacter, Clostridium and Thiococcus were among the major taxa detected after treatment with hypochlorite, representing $13.30 \pm 5.30 \%$ of the total reads (Figure 1). Moreover, known denitrifiers from the genera Acidovorax, Pseudomonas and Thauera, and members of the intestinal tract, Bacteroides, Clostridium and Ruminococcus, were identified in the chlorinated effluent. Chloroflexi with dechlorination capability, i.e., Caldilinea, Bellilinea and Longilinea, as well as microorganisms involved in enhanced biological phosphorus removal, such as Candidatus Accumulibacter and Candidatus Competibacter spp., were also among the most abundant chlorinationresistant genera. On the other hand, Aeromicrobium, Aquabacterium and Hydrogenophaga were the most hypochlorite-susceptible genera $(p<0.01)$, followed by Dechloromonas and Eubacterium $(p<0.05)$. By contrast, the relative abundance of Thiococcus and Thauera increased after chlorination (Figure 1), indicating their effective adaptation to such kinds of water disinfection. In addition, the relative abundances of Bacteroides and Acidovorax were increased, but in a non-significant manner.

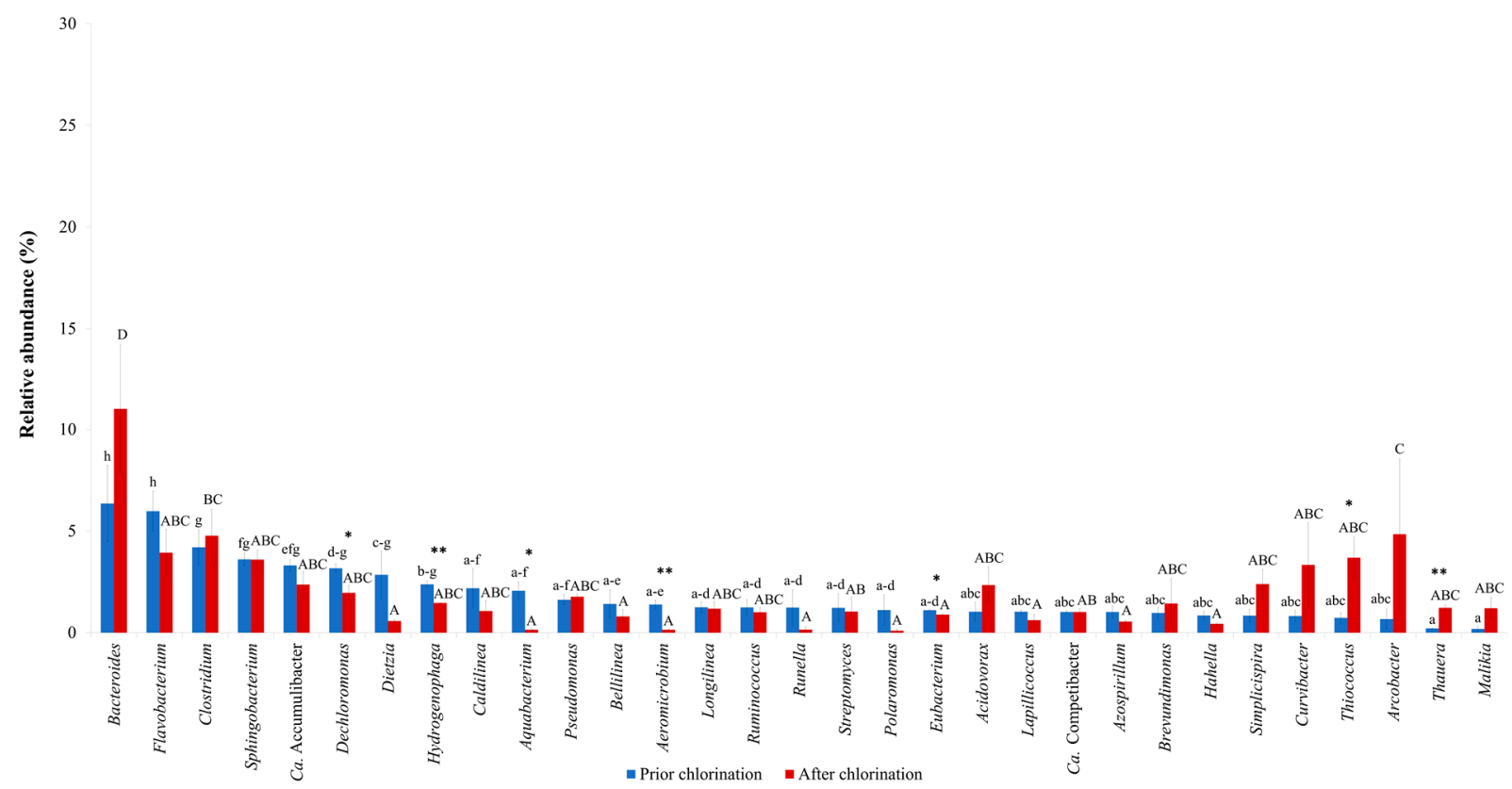

Figure 1. Major bacterial taxa in the effluent of a full-scale WWTP prior to and after chlorination. Letter(s) in common denote no statistically significant differences. $\left({ }^{*}\right)$ or $\left({ }^{*}\right)$ within the same taxon indicates statistically significant difference prior to and after chlorination, at $p<0.01$ or $p<0.05$, respectively.

Bacterial richness was significantly decreased by chlorination $(p<0.05)$, resulting in the decrease in Chao1 index from $560 \pm 24$ to $467 \pm 8$ after disinfection (Figure 2). The Shannon diversity index was not statistically different in non-chlorinated and chlorinated effluent ( $4.54 \pm 0.06$ vs. $4.18 \pm 0.19$, respectively) (Figure 2). In addition, Simpson diversity did not significantly differ in the effluents prior to and after chlorination $(0.98 \pm 0.01$ vs. $0.96 \pm 0.01$, respectively) (Figure 2), reaching values close to 1 . On the other hand, Fisher's 
diversity index lowered significantly from $76.47 \pm 2.56$ prior to chlorination to $63.27 \pm 0.83$ after chlorination $(p<0.01)$ (Figure 2). Pielou's evenness indexes non-significantly differed in the effluent prior to and after chlorination $(0.71 \pm 0.02$ and $0.67 \pm 0.03$, respectively). PCoA showed that the beta diversity of the bacterial communities did not statistically differ in the effluent prior to and after chlorination $\left(F\right.$-value: $\left.1.6101 ; R^{2}: 0.287 ; p<0.30\right)$ (Figure 3 ).
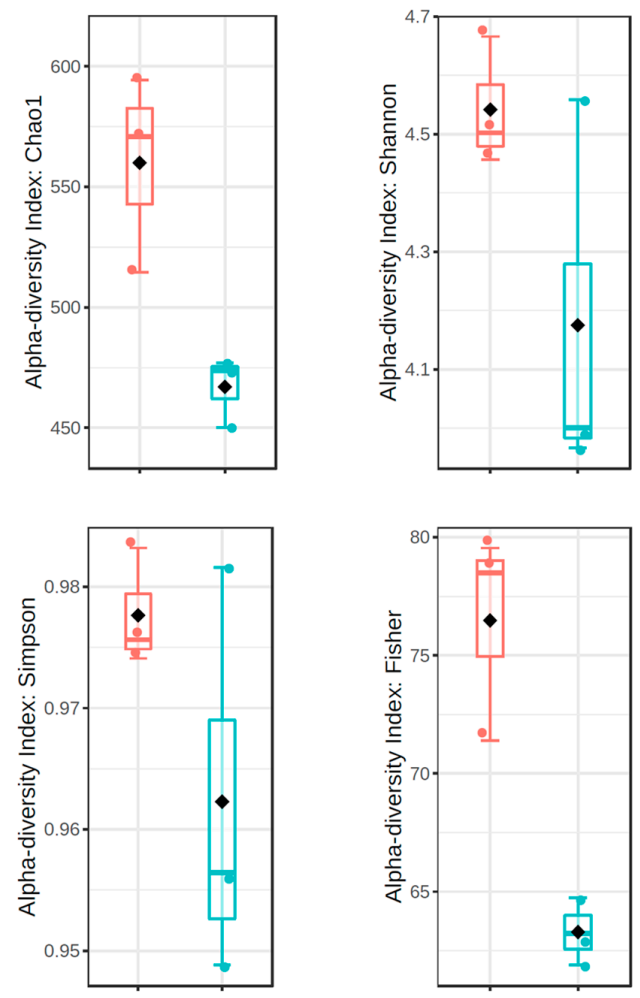

寉 Prior chlorination

审 After chlorination

Figure 2. Diversity indices of bacterial communities in the effluent of WWTP prior to and after chlorination.

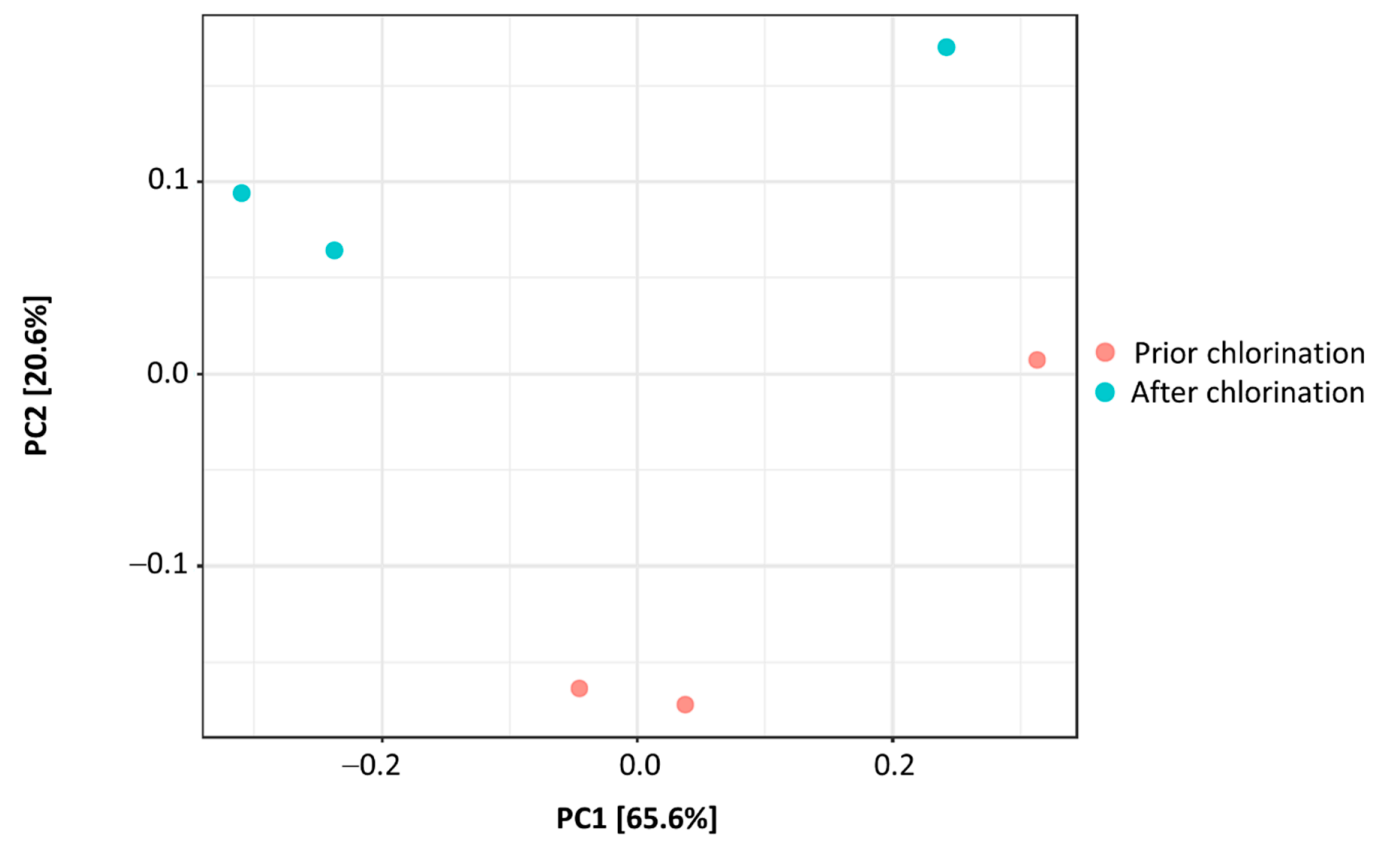

Figure 3. PCoA biplot showing beta diversity of bacterial communities in the effluent of WWTP prior to and after chlorination. 
Perchlorate/chlorate-reducing bacteria [31], including Arcobacter spp. [32], together with organochlorine-reducing bacteria (Table 2) represented a high proportion of the total reads, i.e., $9.13 \pm 1.26 \%$ and $10.13 \pm 3.11 \%$, in the effluent prior to and after chlorination, respectively.

Table 2. Relative abundances of (per)chlorate- and organochlorine-reducing bacteria in the effluent of WWTP prior to and after chlorination.

\begin{tabular}{cccc}
\hline Genus & Prior to Chlorination & After Chlorination & Significance \\
\hline Anaerolinea & $0.02 \pm 0.01$ & $0.01 \pm 0.01$ & $p<0.01$ \\
Bellilinea & $1.42 \pm 0.70$ & $0.80 \pm 0.34$ & n.s. \\
Caldilinea & $2.19 \pm 0.96$ & $1.07 \pm 0.52$ & n.s. \\
Dehalobacter & $0.01 \pm 0.01$ & $0.01 \pm 0.01$ & n.s. \\
Dehalobacterium & At detection limit & At detection limit & n.s. \\
Dehalococcoides & $0.37 \pm 0.03$ & $0.24 \pm 0.06$ & n.s. \\
Dehalogenimonas & n.d. & At detection limit & n.s. \\
Dechloromonas & $3.17 \pm 0.21$ & $1.96 \pm 0.36$ & $p<0.05$ \\
Levilinea & $0.02 \pm 0.01$ & $0.01 \pm 0.01$ & $p<0.05$ \\
Longilinea & $1.25 \pm 0.26$ & $1.19 \pm 0.35$ & n.s. \\
\hline
\end{tabular}

n.d.: not detected; n.s.: not significant.

Ammonia-oxidizing bacteria of the genera Nitrosovibrio and Nitrosomonas, and nitriteoxidizing bacteria of the genera Nitrospira and Candidatus Nitrotoga, were the main nitrifying taxa identified (Table 3), with the relative abundance of Nitrosovibrio being statistically decreased by the addition of disinfectant. As expected, anammox bacteria of the genera Candidatus Kuenenia and Candidatus Anammoximicrobium were restricted in abundance (Table 4). Besides this, polyphosphate-accumulating organisms (PAOs) and their antagonistic glycogen-accumulating organisms (GAOs), which are involved in the enhanced biological phosphorus removal (EBPR) process, were resistant to chlorination since no statistically significant differences were detected in their relative abundances (Table 4).

Table 3. Relative abundances of ammonia- and nitrite-oxidizing bacteria in the effluent of WWTP prior to and after chlorination.

\begin{tabular}{cccc}
\hline Genus & Prior to Chlorination & After Chlorination & Significance \\
\hline Candidatus Nitrotoga & $0.03 \pm 0.02$ & $0.01 \pm 0.01$ & n.s. \\
Nitrobacter & At detection limit & At detection limit & n.s. \\
Nitrosomonas & $0.23 \pm 0.20$ & $0.04 \pm 0.03$ & n.s. \\
Nitrospira & $0.10 \pm 0.03$ & $0.18 \pm 0.05$ & n.s. \\
Nitrosovibrio & $0.27 \pm 0.03$ & n.d. & $p<0.01$ \\
\hline
\end{tabular}

n.d.: not detected; n.s.: not significant.

Table 4. Relative abundances of bacterial taxa influencing enhanced biological phosphorus removal and annamox bacteria in the effluent of WWTP prior to and after chlorination.

\begin{tabular}{cccc}
\hline Genus & Prior to Chlorination & After Chlorination & Significance \\
\hline \multicolumn{4}{c}{ Bacterial Taxa Influencing Enhanced Phosphorus Removal } \\
\hline $\begin{array}{c}\text { Candidatus Accumulibacter } \\
\text { Candidatus Competibacter }\end{array}$ & $3.31 \pm 0.29$ & $2.37 \pm 0.63$ & n.s. \\
\hline \multicolumn{4}{c}{ n.s. } \\
\hline $\begin{array}{c}\text { Candidatus } \\
\text { Anammoximicrobium } \\
\text { Candidatus Kuenenia }\end{array}$ & Annamox bacteria \\
\hline A detection limit & $0.01 \pm 0.01$ & n.s. \\
\hline
\end{tabular}


Chlorination significantly decreased filamentous bacteria from the genera Nocardioides $(p<0.01)$ and Gordonia $(p<0.05)$ (Table 5). Apart from Zoogloea, all other filamentous bacteria decreased in their relative abundance, although in a not significant manner (Table 5). On the other hand, Zoogloea spp. were found to constitute $0.64 \%$ of the bacterial community in the disinfected effluent.

Table 5. Relative abundances of filamentous bacteria in the effluent of WWTP prior to and after chlorination.

\begin{tabular}{cccc}
\hline Genus & Prior to Chlorination & After Chlorination & Significance \\
\hline Beggiatoa & $0.06 \pm 0.03$ & $0.03 \pm 0.02$ & n.s. \\
Candidatus Microthrix & $0.47 \pm 0.21$ & $0.08 \pm 0.04$ & n.s. \\
Gordonia & $0.47 \pm 0.05$ & $0.21 \pm 0.04$ & $p<0.05$ \\
Haliscomenobacter & $0.77 \pm 0.10$ & $0.43 \pm 0.15$ & n.s. \\
Nocardioides & $0.96 \pm 0.10$ & $0.19 \pm 0.04$ & $p<0.01$ \\
Nostocoida Type II & At detection limit & n.d. & n.s. \\
Thiothrix & $0.06 \pm 0.01$ & $0.02 \pm 0.01$ & n.s. \\
Zoogloea & $0.42 \pm 0.02$ & $0.64 \pm 0.08$ & n.s. \\
\hline
\end{tabular}

n.d.: not detected; n.s.: not significant.

Mycobacterium spp. disappeared following the application of the disinfectant, and chlorination also reduced the limited number of Treponema (Table 6). No strains of the genus Escherichia were found. The other potentially pathogenic bacteria identified were detected as a few reads.

Table 6. Relative abundances of potential pathogenic bacteria in the effluent of WWTP prior to and after chlorination.

\begin{tabular}{cccc}
\hline Genus & Prior Chlorination & After Chlorination & Significance \\
\hline Brucella & $0.03 \pm 0.02$ & At detection limit & n.s. \\
Campylobacter & $0.02 \pm 0.01$ & $0.04 \pm 0.02$ & n.s. \\
Enterococcus & $0.01 \pm 0.01$ & $0.01 \pm 0.01$ & n.s. \\
Klebsiella & n.d. & At detection limit & n.s. \\
Legionella & $0.01 \pm 0.01$ & $0.05 \pm 0.04$ & n.s. \\
Mycobacterium & $0.15 \pm 0.05$ & n.d. & p \\
Rickettsia & $0.03 \pm 0.01$ & $0.40 \pm 0.37$ & n.s. \\
Shigella & At detection limit & n.d. & n.s. \\
Spirochaeta & $0.04 \pm 0.01$ & $0.07 \pm 0.04$ & n.s. \\
Treponema & $0.09 \pm 0.02$ & $0.05 \pm 0.00$ & n.s. \\
Vibrio & At detection limit & $0.45 \pm 0.45$ & n.s. \\
\hline
\end{tabular}

n.d.: not detected; n.s.: not significant.

Furthermore, the relative abundance of toxic cyanobacteria did not exceed $0.25 \%$ of the total bacterial population (Table 7). Notably, Anabaena and Microcystis accounted for $0.04 \%$ and $0.02 \%$, respectively. Although the relative abundance of the toxic cyanobacteria was relatively low, it appeared that its abundance remained unaffected by the amount of hypochlorite applied.

Table 7. Relative abundances of cyanobacteria capable of producing toxins in the effluent of WWTP prior to and after chlorination.

\begin{tabular}{cccc}
\hline Genus & Prior to Chlorination & After Chlorination & Significance \\
\hline Anabaena & n.d. & $0.04 \pm 0.01$ & $p<0.01$ \\
Arthrospira & n.d. & At detection limit & n.s. \\
Cyanobacterium & At detection limit & $0.01 \pm 0.01$ & n.s. \\
\hline
\end{tabular}


Table 7. Cont.

\begin{tabular}{cccc}
\hline Genus & Prior to Chlorination & After Chlorination & Significance \\
\hline Cyanothece & n.d. & $0.01 \pm 0.01$ & $p<0.01$ \\
Elstera & At detection limit & At detection limit & n.s. \\
Gloeobacter & $0.08 \pm 0.04$ & $0.08 \pm 0.03$ & n.s. \\
Leptolyngbya & $0.24 \pm 0.16$ & $0.04 \pm 0.02$ & n.s. \\
Microcystis & $0.03 \pm 0.01$ & $0.02 \pm 0.00$ & n.s. \\
Oscillatoria & At detection limit & At detection limit & n.s. \\
Phormidium & At detection limit & At detection limit & n.s. \\
Prochlorococcus & $0.03 \pm 0.01$ & $0.03 \pm 0.01$ & n.s. \\
Pseudanabaena & At detection limit & At detection limit & n.s. \\
Vampirovibrio & $0.01 \pm 0.01$ & At detection limit & n.s. \\
\hline
\end{tabular}

n.d.: not detected; n.s.: not significant.

\section{Discussion}

The high BOD, COD and TSS removal efficiencies in the full-scale wastewater treatment plant indicated its efficient operation. Notably, the quality criteria for $\mathrm{BOD}_{5}, \mathrm{COD}$ and TSS, i.e., 25, 125 and $35 \mathrm{mg} / \mathrm{L}$, respectively, set by the Council Directive 91/271/EEC for effluent discharge, were met after the WWTP operation.

Similar to our study, Aquabacterium and Hydrogenophaga were found to be very sensitive to chlorine in a previous study [21]. Moreover, Pang et al. [8] reported that Pseudomonas and Clostridium were among the most persistent taxa when secondary effluent was treated with $5 \mathrm{mg} \mathrm{Cl}_{2}$ /L. Acidovorax and Pseudomonas are common denitrifies that inhabit activated sludge with a known ability to resist chlorination [33-35], indicating that such taxa can be effectively adapted to the oxidative action of hypochlorite. Multiple layers of extracellular polymeric substances (EPS) and biofilm formation are key parameters in the adaptation of such taxa, since the penetration of the disinfectant is prevented [36]. Accordingly, bacterial taxa detected in the current study, such as Zoogloea, Thauera, Dechloromonas and Candidatus Accumulibacter, have been reported to harbor gene clusters for EPS synthesis and floc formation in their genomes [37]. Moreover, Clostridium and Bacteroides spp., which are indicators of human fecal contamination, are considered as chlorination-resistant microorganisms effectively adapted to high doses of disinfectant [23,38]. Flavobacterium and Sphingobacterium have been also reported to survive disinfection through biofilm formation [39]. In particular, members of the genus Flavobacterium are known to persist through chlorination [40]. In addition, the low dissolved oxygen level in the secondary sedimentation tank favored or simply retained the aerotolerant/anaerobic taxa of the intestinal tract, such as the strains of the genera Bacteroides, Arcobacter and Clostridium.

Estimation of the Shannon diversity index showed no significant alterations in the bacterial diversity with the application of hypochlorite. Moreover, Simpson's index values close to 1 indicated that bacterial communities were highly diverse prior to and after chlorination. On the other hand, Fisher's diversity index denoted decreased species abundance at the logarithmic scale. Pang et al. [8] reported a decrease in the Chao1 index of the bacterial community in the effluent of some of the examined WWTPs after chlorination, and similar results were also provided by Lin et al. [21]. Indeed, the decrease in Chao1 and Fisher, and not in Shannon and Simpson, indices implies a higher impact of chlorination on the richness and abundance of bacterial taxa rather than on the communities' evenness, as Pielou's evenness indexes showed. Moreover, estimation of beta-diversity prior to and after chlorination indicated similar bacterial community structures and minor effects of chlorination on the diversity.

In this study, no statistically significant effect of the addition of hypochlorite on the abundance of members of the phylum Chloroflexi with dechlorination capability was observed, indicating the resistance of these microbial constituents to chlorination. (Per)chloratereducing bacteria convert perchlorate to chlorate and then to chlorite [31], wherein hypochlorite is formed as the transient intermediate [41,42]. Thus, (per)chlorate-respiring bacteria possess the genetic capability to deal with the toxic effects of hypochlorite. In addition, 
bacteria from the genera Dehalobacter, Dehalococcoides and Dehalogenimonas are also capable of organochlorine respiration [43-45]. As a consequence of chlorination, hypochlorite can react with organic compounds and form organochlorinated derivatives with harmful effects on aquatic organisms and humans. Thus, the relatively high abundance of Chloroflexi can be attributed to their dechlorinating ability [46].

Similar to the current study, Tian et al. [47] and Numberger et al. [2] reported the survival of Candidatus Accumulibacter after disinfection with ozone and UV radiation, respectively. Apart from the resistance of these uncultured taxa to chlorination, the possibility of reducing (per)chlorate or organochlorinated compounds could not be ruled out. Taking into account that PAOs, performing EBPR, are able to grow in the anoxic zone, and the addition of hypochlorites in the absence of oxygen adjusts redox potential to negative values near zero (anoxic conditions), the ability of such microbiota to reduce perchlorate or organochlorines deserves further investigation. Moreover, nitrifiers of the genera Nitrosomonas and Nitrospira have been found to proliferate after chlorination [48].

In the present study, the abundance of filamentous bacteria responsible for sludge bulking and foaming can be considered as low in both non-disinfected and disinfected effluent. Filamentous bacteria are the causing agents of bulking and foaming in WWTPs, which can reduce activated sludge sedimentability, thus negatively affecting the water quality of the effluent [49]. Notably, such foams have recently been found to carry antibioticresistant genes and human pathogenic bacteria, spreading them in the recipient water bodies [50]. Caravelli et al. [51] reported that chlorination resulted in the inhibition of filamentous bacteria in activated sludge. On the other hand, similarly to our results, Nocardioides was found to be among the microbial constituents of a biofilm developed in a chlorinated drinking water distribution system [52]. Besides this, Zoogloea spp. are known for their ability to form specific cell aggregates enclosed in gelatinous matrices, a fact that facilitate their resistance to chlorination.

Chlorination is considered as a necessary treatment to significantly reduce the percentage of opportunistic pathogens. Regarding the presence of potentially pathogenic bacteria in the current study, Illumina sequencing revealed that their relative abundance was extremely low, even in the non-disinfected effluent, indicating a low risk from the presence of opportunistic pathogenic bacteria. In particular, no risk from fecal coliform contamination was found in the current case since Escherichia strains were not detected. Moreover, Mycobacterium spp. disappeared following the application of the disinfectant and a limited number of Treponema sequences were detected after chlorination. Similar to our study, Mycobacterium was included by Park et al. [23] in the list of the most chlorinesensitive taxa. The other potentially pathogenic bacteria detected as a few reads are unlikely to present a threat to the ecosystem and human health.

Cyanobacteria, which can secrete toxic substances that may adversely affect the ecology of aquatic organisms and ultimately human health, were also investigated [53]. As in the case of opportunistic pathogenic bacteria, the activated sludge process minimized the risk deriving from the presence of toxic cyanobacteria. Anabaena and Microcystis, which are considered as the main cyanobacterial taxa-secreting toxins [54,55], were present in negligible abundances. It should also be taken into account that their growth was not favored in the aeration tank, due to the high oxygen supply and increased growth of heterotrophs under aerobic conditions, and to the dark-brown color of the mixed liquor, restricting the photosynthetic activity of cyanobacteria.

Although there is no clear trend as regards the susceptibility of taxa to common disinfection methods, it appears that Candidatus Accumulibacter, Candidatus Competibacter, Clostridium, Flavobacterium, Pseudomonas and Simplicispira are capable of resisting conventional disinfection approaches (Table 8). This indicates that additional treatment methods, such as membrane or advanced oxidation processes systems, may be required in the case of effluent discharge in sensitive recipients. 
Table 8. Effect of disinfection methods on effluent microbiota in municipal WWTPs: susceptible and resistant taxa to disinfection as detected by high-throughput amplicon sequencing.

\begin{tabular}{|c|c|c|c|}
\hline Disinfection Method & Susceptible Taxa & Resistant Taxa & Reference \\
\hline Monochloramine & Arcobacter, Nitrospira, Sphingobium & $\begin{array}{c}\text { Chryseobacterium, Cloacibacterium, } \\
\text { Clostridium, Mycobacterium, } \\
\text { Pseudomonas, Sphingomonas, } \\
\text { Streptococcus, Undibacterium }\end{array}$ & [15] \\
\hline $\mathrm{H}_{2} \mathrm{O}_{2}$ & Denitratisoma, Thauera & Anaerolinea, Filimonas & [15] \\
\hline $\mathrm{UV}^{1}$ & $\begin{array}{c}\text { Acetoanaerobium, Acidovorax, } \\
\text { Acinetobacter, Aeromonas, } \\
\text { Anaerosinus, Aquabacterium, } \\
\text { Arcobacter, Comamonas, } \\
\text { Enterococcus, Faecalibacterium, } \\
\text { Paracoccus, Proteocatella, } \\
\text { Streptococcus, Subdoligranulum, } \\
\text { Trichococcus, Uruburuella, } \\
\text { Veillonella }\end{array}$ & $\begin{array}{c}\text { Ca. Accumulibacter, Ca. Competibacter, } \\
\text { Ca. Nitrotoga, } \\
\text { Chryseobacterium, Cupriavidus, } \\
\text { Dechloromonas, Geothrix, Nitrosomonas, } \\
\text { Nitrospira, Rhodoferax, Simplicispira, } \\
\text { Thauera, Zoogloea }\end{array}$ & [2] \\
\hline $\mathrm{UV}-\mathrm{C} / \mathrm{H}_{2} \mathrm{O}_{2} / \mathrm{IDS}-\mathrm{Cu}^{2}$ & N.R. & Acinetobacter, Pantoea, Pseudomonas & [16] \\
\hline Chlorination $^{4}$ & $\begin{array}{c}\text { Acinetobacter, Arcobacter, Azonexus, } \\
\text { Azospira, Bifidobacterium, } \\
\text { Chitinimonas, Comamonas, } \\
\text { Dechloromonas, Enterococcus, } \\
\text { Lactobacillales, Laribacter, Neisseria, } \\
\text { Nitrosomonas, } \\
\text { Propionivibrio, Rheinheimera, } \\
\text { Salmonella, Shewanella, } \\
\text { Thauera, Tolumonas, Vitreoscilla, } \\
\text { Zoogloea }\end{array}$ & $\begin{array}{c}\text { Aquabacterium, Chryseobacterium, } \\
\text { Clostridium, Flavobacterium, } \\
\text { Gemmata, Hydrogenophaga, Legionella, } \\
\text { Mycobacterium, Pseudomonas, } \\
\text { Rubrivivax, Turicibacter, Veillonella }\end{array}$ & {$[3,8]$} \\
\hline
\end{tabular}

Acidovorax, Arcobacter, Azospirillum, Bacteroides, Bellilinea,

Breoundimonas, Caldilinea, Ca.

Accumulibacter, $\mathrm{Ca}$. Competibacter,

Aeromicrobium, Aquabacterium,

Chlorination Dechloromonas, Eubacterium, Hydrogenophaga ${ }^{3}$

Clostridium, Curvibacter, Dietzia, Flavobacterium, Hahella,

Lapillicoccus, Longilinea, Malikia, Polaromonas, Pseudomonas,

Ruminococcus, Runella, Simplicispira, Sphingobacterium, Streptomyces, Thauera, Thiococcus $^{3}$

\footnotetext{
${ }^{1}$, municipal wastewater plus minor percentage of industrial wastewater; ${ }^{2}$, IDS-Cu, iminodisuccinic acid complex; ${ }^{3}$, only major taxa reported; N.R., not reported; ${ }^{4}$, Aeromonas was reported as susceptible and resistant by Pang et al. [8] and Greay et al. [3], respectively, whereas the opposite was reported for Corynebacterium and Streptococcus by the same authors.
}

\section{Conclusions}

Common inhabitants of intestinal tract, i.e., Bacteroides, Arcobacter and Clostridium, were found to survive chlorination and constitute the main microbiota detected in the disinfected effluent. In addition, denitrifiers of the activated sludge systems capable of forming biofilms, such as Acidovorax, Pseudomonas and Thauera, as well as Chloroflexi with dechlorination capabilities and bacteria involved in enhanced biological phosphorus removal, such as Candidatus Accumulibacter and Candidatus Competibacter, were included in the list of chlorination-resistant genera. Chlorination significantly affected the decreased filamentous bacteria of the genera Nocardioides and Gordonia, whereas Zoogloea proliferated in the chlorinated effluent. Perchlorate/chlorate respiration and organochlorine degradation seem to be key processes in the resistance of (per)chlorate- and organochlorine-reducing bacteria, detected in the current study (Table 2), to chlorination. No fecal coliform contamination was observed since Escherichia spp. were not detected. Mycobacterium spp. were 
absent, whereas a reduced number of Treponema was detected in the chlorinated effluent. Toxin-producing cyanobacteria of the genera Anabaena and Microcystis were identified in low abundances. This indicates that tertiary treatment methods, which result either in the complete retention or elimination of toxic cyanobacteria, such as membrane or advanced oxidation processes systems, may be more appropriate for improving effluent quality in recipients of eutrophication-sensitive areas.

Supplementary Materials: The following is available online at https:/ / www.mdpi.com/2075-1729/ 11/1/68/s1, Table S1: Minor taxa identified in the effluent of the full-scale municipal WWTP prior to and after chlorination.

Author Contributions: Conceptualization, I.Z., N.R., I.K. and S.N.; methodology, I.Z., N.R. and M.A.; formal analysis, I.Z., N.R., I.K., P.M., G.S. and S.N.; investigation, I.Z., N.R., M.A. and S.N.; writing—original draft preparation, I.Z., N.R. and S.N.; writing—review and editing, I.Z., N.R., I.K., P.M., G.S. and S.N.; supervision, S.N. All authors have read and agreed to the published version of the manuscript.

Funding: This research received no external funding.

Institutional Review Board Statement: Not applicable.

Informed Consent Statement: Not applicable.

Conflicts of Interest: The authors declare no conflict of interest.

\section{References}

1. Guadagnini, R.A.; Dos Santos, L.U.; Franco, R.M.B.; Guimarães, J.R. Inactivation of bacteria and helminth in wastewater treatment plant effluent using oxidation processes. Water Sci. Technol. 2013, 68, 1825-1829. [CrossRef] [PubMed]

2. Numberger, D.; Ganzert, L.; Zoccarato, L.; Mühldorfer, K.; Sauer, S.; Grossart, H.P.; Greenwood, A.D. Characterization of bacterial communities in wastewater with enhanced taxonomic resolution by full-length 16S rRNA sequencing. Sci. Rep. $2019,9,9673$. [CrossRef] [PubMed]

3. Greay, T.L.; Gofton, A.W.; Zahedi, A.; Paparini, A.; Linge, K.L.; Joll, C.A.; Ryan, U.M. Evaluation of 16 S next-generation sequencing of hypervariable region 4 in wastewater samples: An unsuitable approach for bacterial enteric pathogen identification. Sci. Total Environ. 2019, 670, 1111-1124. [CrossRef] [PubMed]

4. Beattie, R.E.; Skwor, T.; Hristova, K.R. Survivor microbial populations in post-chlorinated wastewater are strongly associated with untreated hospital sewage and include ceftazidime and meropenem resistant populations. Sci. Total Environ. 2020, 740, 140186. [CrossRef]

5. Wolff, D.; Krah, D.; Dötsch, A.; Ghattas, A.K.; Wick, A.; Ternes, T.A. Insights into the variability of microbial community composition and micropollutant degradation in diverse biological wastewater treatment systems. Water Res. 2018, 143, 313-324. [CrossRef]

6. Sousa, J.M.; Macedo, G.; Pedrosa, M.; Becerra-Castro, C.; Castro-Silva, S.; Pereira, M.F.R.; Silva, A.M.; Nunes, O.C.; Manaia, C.M. Ozonation and $\mathrm{UV}_{254} \mathrm{~nm}$ radiation for the removal of microorganisms and antibiotic resistance genes from urban wastewater. J. Hazard. Mater. 2017, 323, 434-441. [CrossRef]

7. Yao, X.; Hu, X.; Liu, Y.; Wang, X.; Hong, X.; Chen, X.; Pillai, S.C.; Dionysiou, D.D.; Wang, D. Simultaneous photocatalytic degradation of ibuprofen and $\mathrm{H}_{2}$ evolution over Au/sheaf-like $\mathrm{TiO}_{2}$ mesocrystals. Chemosphere 2020, 261, 127759. [CrossRef]

8. Pang, Y.C.; Xi, J.Y.; Xu, Y.; Huo, Z.Y.; Hu, H.Y. Shifts of live bacterial community in secondary effluent by chlorine disinfection revealed by Miseq high-throughput sequencing combined with propidium monoazide treatment. Appl. Microbiol. Biotechnol. 2016, 100, 6435-6446. [CrossRef]

9. Francy, D.S.; Stelzer, E.A.; Bushon, R.N.; Brady, A.M.G.; Williston, A.G.; Riddell, K.R.; Borchardt, M.A.; Spencer, S.K.; Gellner, T.M. Comparative effectiveness of membrane bioreactors, conventional secondary treatment, and chlorine and UV disinfection to remove microorganisms from municipal wastewaters. Water Res. 2012, 46, 4164-4178. [CrossRef]

10. Papadimitriou, T.; Kormas, K.; Dionysiou, D.D.; Laspidou, C. Using $\mathrm{H}_{2} \mathrm{O}_{2}$ treatments for the degradation of cyanobacteria and microcystins in a shallow hypertrophic reservoir. Environ. Sci. Pollut. Res. 2016, 23, 21523-21535. [CrossRef]

11. Nasuhoglu, D.; Isazadeh, S.; Westlund, P.; Neamatallah, S.; Yargeau, V. Chemical, microbial and toxicological assessment of wastewater treatment plant effluents during disinfection by ozonation. Chem. Eng. J. 2018, 346, 466-476. [CrossRef]

12. Pedersen, P.O.; Brodersen, E.; Cecil, D. Disinfection of tertiary wastewater effluent prior to river discharge using peracetic acid; treatment efficiency and results on by-products formed in full scale tests. Water Sci. Technol. 2013, 68, 1852-1856. [CrossRef] [PubMed]

13. Hassaballah, A.H.; Nyitrai, J.; Hart, C.H.; Dai, N.; Sassoubre, L.M. A pilot-scale study of peracetic acid and ultraviolet light for wastewater disinfection. Environ. Sci. Water Res. Technol. 2019, 5, 1453-1463. [CrossRef] 
14. Valero, P.; Verbel, M.; Silva-Agredo, J.; Mosteo, R.; Ormad, M.P.; Torres-Palma, R.A. Electrochemical advanced oxidation processes for Staphylococcus aureus disinfection in municipal WWTP effluents. J. Environ. Manag. 2017, 198, 256-265. [CrossRef] [PubMed]

15. Yang, Y.; Cheng, D.; Li, Y.; Yu, L.; Gin, K.Y.H.; Chen, J.P.; Reinhard, M. Effects of monochloramine and hydrogen peroxide on the bacterial community shifts in biologically treated wastewater. Chemosphere 2017, 189, 399-406. [CrossRef]

16. Di Cesare, A.; De Carluccio, M.; Eckert, E.M.; Fontaneto, D.; Fiorentino, A.; Corno, G.; Prete, P.; Cucciniello, R.; Proto, A.; Rizzo, L. Combination of flow cytometry and molecular analysis to monitor the effect of UVC $/ \mathrm{H}_{2} \mathrm{O}_{2}$ vs $\mathrm{UVC} / \mathrm{H}_{2} \mathrm{O}_{2} / \mathrm{Cu}$-IDS processes on pathogens and antibiotic resistant genes in secondary wastewater effluents. Water Res. 2020, 184, 116194. [CrossRef]

17. Martínez-Hernández, S.; Vázquez-Rodríguez, G.A.; Beltrán-Hernández, R.I.; Prieto-García, F.; Miranda-López, J.M.; FrancoAbuín, C.M.; Álvarez-Hernández, A.; Iturbe, U.; Coronel-Olivares, C. Resistance and inactivation kinetics of bacterial strains isolated from the non-chlorinated and chlorinated effluents of a WWTP. Int. J. Environ. Res. Public Health 2013, 10, $3363-3383$. [CrossRef]

18. Alexander, J.; Karaolia, P.; Fatta-Kassinos, D.; Schwartz, T. Impacts of advanced oxidation processes on microbiomes during wastewater treatment. In Advanced Treatment Technologies for Urban Wastewater Reuse-The Handbook of Environmental Chemistry; Fatta-Kassinos, D., Dionysiou, D., Kümmerer, K., Eds.; Springer: Cham, Switzerland, 2015; Volume 45, pp. 129-144.

19. Kulkarni, P.; Olson, N.D.; Paulson, J.N.; Pop, M.; Maddox, C.; Claye, E.; Rosenberg Goldstein, R.E.; Sharma, M.; Gibbs, S.G.; Mongodin, E.F.; et al. Conventional wastewater treatment and reuse site practices modify bacterial community structure but do not eliminate some opportunistic pathogens in reclaimed water. Sci. Total Environ. 2018, 639, 1126-1137. [CrossRef]

20. Nasser, A.M.; Benisti, N.L.; Ofer, N.; Hovers, S.; Nitzan, Y. Comparative reduction of Giardia cysts, F+ coliphages, sulphite reducing clostridia and fecal coliforms by wastewater treatment processes. J. Environ. Sci. Health A 2017, 52, 144-148. [CrossRef]

21. Lin, Y.; Li, D.; Zeng, S.; He, M. Changes of microbial composition during wastewater reclamation and distribution systems revealed by high-throughput sequencing analyses. Front. Environ. Sci. Eng. 2016, 10, 539-547. [CrossRef]

22. Li, D.; Zeng, S.; Gu, A.Z.; He, M.; Shi, H. Inactivation, reactivation and regrowth of indigenous bacteria in reclaimed water after chlorine disinfection of a municipal wastewater treatment plant. J. Environ. Sci. 2013, 25, 1319-1325. [CrossRef]

23. Park, E.; Mancl, K.M.; Tuovinen, O.H.; Bisesi, M.S.; Lee, J. Ensuring safe reuse of residential wastewater: Reduction of microbes and genes using peat biofilter and batch chlorination in an on-site treatment system. J. Appl. Microbiol. 2016, 121, 1777-1788. [CrossRef] [PubMed]

24. Limayem, A.; Wasson, S.; Mehta, M.; Pokhrel, A.R.; Patil, S.; Nguyen, M.; Chen, J.; Nayak, B. High-throughput detection of bacterial community and its drug-resistance profiling from local reclaimed wastewater plants. Front. Cell Infect. Microbiol. 2019, 9, 303. [CrossRef] [PubMed]

25. Clesceri, L.S.; Greenberg, A.E.; Eaton, A.D. Standard Methods for the Examination of Water and Wastewater; American Public Health Association (APHA): Washington, DC, USA, 1998.

26. Remmas, N.; Roukouni, C.; Ntougias, S. Bacterial community structure and prevalence of Pusillimonas-like bacteria in aged landfill leachate. Environ. Sci. Pollut. Res. 2017, 24, 6757-6769. [CrossRef]

27. Masella, A.P.; Bartram, A.K.; Truszkowski, J.M.; Brown, D.G.; Neufeld, J.D. PANDAseq: Paired-end assembler for Illumina sequences. BMC Bioinform. 2012, 13, 31. [CrossRef]

28. Edgar, R.C. UNOISE2: Improved error-correction for Illumina 16S and ITS amplicon sequencing. bioRxiv 2016, 081257. [CrossRef]

29. Dhariwal, A.; Chong, J.; Habib, S.; King, I.L.; Agellon, L.B.; Xia, J. MicrobiomeAnalyst: A web-based tool for comprehensive statistical, visual and meta-analysis of microbiome data. Nucleic Acids Res. 2017, 45, W180-W188. [CrossRef]

30. Hammer, Ø. (Natural History Museum, University of Oslo, Olso, Norway). PAST-Paleontological Statistics; Version 3.25., 2019. Available online: https:/ / folk.uio.no/ohammer/past/index.html (accessed on 18 January 2021).

31. Bardiya, N.; Bae, J.H. Dissimilatory perchlorate reduction: A review. Microbiol. Res. 2011, 166, 237-254. [CrossRef]

32. DuBois, J.L.; Ojha, S. Production of dioxygen in the dark: Dismutases of oxyanions. Met. Ions Life Sci. 2015, 15, 45-87. [CrossRef]

33. Zhu, Z.; Shan, L.; Hu, F.; Li, Z.; Zhong, D.; Yuan, Y.; Zhang, J. Biofilm formation potential and chlorine resistance of typical bacteria isolated from drinking water distribution systems. RSC Adv. 2020, 10, 31295-31304. [CrossRef]

34. Mao, G.; Song, Y.; Bartlam, M.; Wang, Y. Long-term effects of residual chlorine on Pseudomonas aeruginosa in simulated drinking water fed with low AOC medium. Front. Microbiol. 2018, 9, 879. [CrossRef] [PubMed]

35. Jia, S.; Shi, P.; Hu, Q.; Li, B.; Zhang, T.; Zhang, X.X. Bacterial community shift drives antibiotic resistance promotion during drinking water chlorination. Environ. Sci. Technol. 2015, 49, 12271-12279. [CrossRef] [PubMed]

36. Bridier, A.; Briandet, R.; Thomas, V.; Dubois-Brissonnet, F. Resistance of bacterial biofilms to disinfectants: A review. Biofouling 2011, 27, 1017-1032. [CrossRef] [PubMed]

37. An, W.; Guo, F.; Song, Y.; Gao, N.; Bai, S.; Dai, J.; Wei, H.; Zhang, L.; Yu, D.; Xia, M.; et al. Comparative genomics analyses on EPS biosynthesis genes required for floc formation of Zoogloea resiniphila and other activated sludge bacteria. Water Res. 2016, 102, 494-504. [CrossRef]

38. Durán, A.E.; Muniesa, M.; Mocé-Llivina, L.; Campos, C.; Jofre, J.; Lucena, F. Usefulness of different groups of bacteriophages as model micro-organisms for evaluating chlorination. J. Appl. Microbiol. 2003, 95, 29-37. [CrossRef]

39. Towhid, S.T. Microbial interaction as a determinant of the quality of supply drinking water: A conceptual analysis. Front. Public Health 2018, 6, 184. [CrossRef]

40. Li, C.; Dong, F.; Feng, L.; Zhao, J.; Zhang, T.; Cizmas, L.; Sharma, V.K. Bacterial community structure and microorganism inactivation following water treatment with ferrate(VI) or chlorine. Environ. Chem. Lett. 2017, 15, 525-530. [CrossRef] 
41. Wang, O.; Coates, J.D. Biotechnological applications of microbial (per)chlorate reduction. Microorganisms 2017, 5, 76. [CrossRef]

42. Mehta-Kolte, M.G.; Loutey, D.; Wang, O.; Youngblut, M.D.; Hubbard, C.G.; Wetmore, K.M.; Conrad, M.E.; Coates, J.D. Mechanism of $\mathrm{H}_{2} \mathrm{~S}$ oxidation by the dissimilatory perchlorate-reducing microorganism Azospira suillum PS. mBio 2017, 8, e02023-16. [CrossRef]

43. Lee, M.; Low, A.; Zemb, O.; Koenig, J.; Michaelsen, A.; Manefield, M. Complete chloroform dechlorination by organochlorine respiration and fermentation. Environ. Microbiol. 2012, 14, 883-894. [CrossRef]

44. Hug, L.A.; Maphosa, F.; Leys, D.; Löffler, F.E.; Smidt, H.; Edwards, E.A.; Adrian, L. Overview of organohalide-respiring bacteria and a proposal for a classification system for reductive dehalogenases. Philos. Trans. R. Soc. B Biol. Sci. 2013, 368. [CrossRef] [PubMed]

45. Jugder, B.E.; Ertan, H.; Bohl, S.; Lee, M.; Marquis, C.P.; Manefield, M. Organohalide respiring bacteria and reductive dehalogenases: Key tools in organohalide bioremediation. Front. Microbiol. 2016, 7, 249. [CrossRef] [PubMed]

46. Krzmarzick, M.J.; Crary, B.B.; Harding, J.J.; Oyerinde, O.O.; Leri, A.C.; Myneni, S.C.B.; Novak, P.J. Natural niche for organohaliderespiring Chloroflexi. Appl. Environ. Microbiol. 2012, 78, 393-401. [CrossRef] [PubMed]

47. Tian, S.; Tian, Z.; Yang, H.; Yang, M.; Zhang, Y. Detection of viable bacteria during sludge ozonation by the combination of ATP assay with PMA-miseq sequencing. Water 2017, 9, 166. [CrossRef]

48. Eichler, S.; Christen, R.; Höltje, C.; Westphal, P.; Bötel, J.; Brettar, I.; Mehling, A.; Höfle, M.G. Composition and dynamics of bacterial communities of a drinking water supply system as assessed by RNA- and DNA-based 16S rRNA gene fingerprinting. Appl. Environ. Microbiol. 2006, 72, 1858-1872. [CrossRef]

49. Li, B.B.; Peng, Z.Y.; Zhi, L.L.; Li, H.B.; Zheng, K.K.; Li, J. Distribution and diversity of filamentous bacteria in wastewater treatment plants exhibiting foaming of Taihu Lake Basin, China. Environ. Pollut. 2020, 267, 115644. [CrossRef]

50. Zhang, H.; Zhang, Z.; Song, J.; Cai, L.; Yu, Y.; Fang, H. Foam shares antibiotic resistomes and bacterial pathogens with activated sludge in wastewater treatment plants. J. Hazard. Mater. 2021, 408, 124855. [CrossRef]

51. Caravelli, A.; Giannuzzi, L.; Zaritzky, N. Effect of chlorine on filamentous microorganisms present in activated sludge as evaluated by respirometry and INT-dehydrogenase activity. Water Res. 2004, 38, 2395-2405. [CrossRef]

52. Liu, J.; Ren, H.; Ye, X.; Wang, W.; Liu, Y.; Lou, L.; Cheng, D.; He, X.; Zhou, X.; Qiu, S.; et al. Bacterial community radial-spatial distribution in biofilms along pipe wall in chlorinated drinking water distribution system of East China. Appl. Microbiol. Biotechnol. 2017, 101, 749-759. [CrossRef]

53. Rastogi, R.P.; Madamwar, D.; Incharoensakdi, A. Bloom dynamics of cyanobacteria and their toxins: Environmental health impacts and mitigation strategies. Front. Microbiol. 2015, 6, 1254. [CrossRef]

54. Catherine, Q.; Susanna, W.; Isidora, E.S.; Mark, H.; Aurélie, V.; Jean-François, H. A review of current knowledge on toxic benthic freshwater cyanobacteria-Ecology, toxin production and risk management. Water Res. 2013, 47, 5464-5479. [CrossRef] [PubMed]

55. Chia, M.A.; Jankowiak, J.G.; Kramer, B.J.; Goleski, J.A.; Huang, I.S.; Zimba, P.V.; do Carmo Bittencourt-Oliveira, M.; Gobler, C.J. Succession and toxicity of Microcystis and Anabaena (Dolichospermum) blooms are controlled by nutrient-dependent allelopathic interactions. Harmful Algae 2018, 74, 67-77. [CrossRef] [PubMed] 